\title{
Synthesis of Tri- and Tetracycle Compounds via Reaction of 1,3-Decalinediones and 4-Hydroxycoumarines with 2-Acetyl-2-Cyclohexenes and Biological Testing
}

\author{
Anatoliyi N. Pyrko', Gennadiyi S. Lyubin², Stanislove L. Bondarev ${ }^{3}$ \\ ${ }^{1}$ International State Ecological University Named after A. D. Sakharov, Minsk, Belarus \\ ${ }^{2}$ Institute of Bioorganic Chemistry NAS of Belarus, Minsk, Belarus \\ ${ }^{3}$ Minsk State Higher Radiotechnical College, Minsk, Belarus \\ Email: pyrko1950@mail.ru
}

Received 4 April 2014; revised 20 May 2014; accepted 8 July 2014

Copyright (C) 2014 by authors and OALib.

This work is licensed under the Creative Commons Attribution International License (CC BY).

http://creativecommons.org/licenses/by/4.0/

(c) (i) Open Access

\section{Abstract}

2-Acetyl-5, 5-dimethyl-2-cyclohexen-l-one reacts with decalin-1,3-dions (9a, b) and 4-hydroxycoumarins $(13 a, b)$ following the pattern of a Michael addition with the formation of tricyclic compounds (10a, $b$ and $14 a, b)$. In the case of unsubstituted 2-acetyl-2-cyclohexen-l-one reaction with 4-hydroxycoumarine follows pattern of a DieIs-Alder heterodiene condensation to form tetracycle (15). Dehydration of both types of adduct gives tetracyclic compounds $(11 a, b$ and 16a, $b$, c). Coumarine derivatives $(14 a, b, 15,16 c)$ were tested for anticoagulative activity.

\section{Keywords}

Synthesis, Decalindion and Coumarine Derivatives, Anticoagulative Activity

Subject Areas: Biochemistry, Biological Chemistry, Biotechnology, Organic Chemistry

\section{Introduction}

Despite of the fact that total synthesis of base natural steroids have been accomplished, only the synthesis of aromatic ones is effective. That is why there is still necessity of the methods which permit the rapid formation of their tetracyclic framework. A number of steroid heterocyclic analogues, their region- and stereoisomers can be

How to cite this paper: Pyrko, A.N., Lyubin, G.S. and Bondarev, S.L. (2014) Synthesis of Tri- and Tetracycle Compounds via Reaction of 1,3-Decalinediones and 4-Hydroxycoumarines with 2-Acetyl-2-Cyclohexenes and Biological Testing. Open Access Library Journal, 1: e749. http://dx.doi.org/10.4236/oalib.1100749 
obtained only by the total synthesis. Incorporating heteroatoms into the steroid skeleton is an important task for pharmacological research because it allows finding out the substances having good therapeutic effects combining with the lack of hormonal activities.

At the beginning (1935) of search for routs for total synthesis of steroids, Robinson et al. developed $\mathrm{AB} \rightarrow$ $\mathrm{ABD} \rightarrow \mathrm{ABCD}$ scheme for building the cyclopentano- and cyclohexanophenanthren skeleton, starting with $\alpha$-tetralones and appropriate acetylcycloalkens (1a, b) (Figure 1) [1] [2].

The use in this scheme of heterocyclic analogs of $\alpha$-tetralone or acetylcycloalkens gives steroid analogs with heteroatoms in cycles A, B and D [3]-[5]. However, in the compounds obtained in this manner, typical natural steroids oxygen function or the side chain at position 17 (17a) is absent. Attempts to introduce them by chemical [6] or microbiological [7] methods in already obtained molecule have been unsuccessful.

Consequently, it was logical to propose as being highly promising the use of acetylcycloalkenones (3a, $\mathbf{b})$ in this scheme, which made it possible, or so it was believed, to obtain the ABCD fragment (2a, b), already containing the 12,17-dicarbonyl grouping.

For the first time this type of compound-acetylcyclohexenones (3b, c) were obtained in 1972 [8]. It has been shown that they are easily isomerized by heating in the presence of acids and bases in ketodienols (4b, c), which can not be used as an acceptor of Michael addition reaction with enolate anions of $\alpha$-tetralones and they can not be involved in Robinson synthetic scheme.

Therefore, it was decided to use in this synthetic scheme acetylcycloalkenoles (5a, b) instead of acetylcycloalkenones (3a, b). We accomplished the synthesis of these compounds by two ways from cycloalkenons [9] and cyclic $\beta$-triketones [10]. Unfortunately, reaction of ketoenols (5a, b) with 6-methoxytetralon gave tetra-and hexacyclic compounds with low yield [11].

We have developed an efficient two-step synthesis of ketodienols (4b, c) [12] from corresponding 2-acetylcyclohexan-1,3-diones, which allowed them to explore their chemical properties. It has been shown that in the presence of bases, they can easily enter the reaction with 1,3-cyclohexanediones giving adducts of Michael addition (6a, b, c). Intramolecular aldol condensation as in Robinson annulation was not observed. Dehydration of bicycles $(\mathbf{6} \mathbf{a}, \mathbf{b}, \mathbf{c})$ in the presence of acid leads to the formation of pyran ring with the formation of tricycles (7a, b). Interaction of ketodienols with $\beta$-enaminones gives new derivatives hexahydroisoquinoline $(\mathbf{8 a}, \mathbf{b}, \mathbf{c})$ and decahydrophenanthridine (7d, e) [13] [14]. It should be noted that currently it has been revealed that there is an effective way to obtain not only acetylcyclohexenone (3b) [15], but also acetylcyclopentenenone (3a) [16] and other related endions [17]-[19] from corresponding cis- $\beta$-diketones by their selenenylation followed by selenoxide elimination of with hydrogen peroxide. The photochemical [2 + 2] and [2 + 4] addition reactions of acetylcyclo-

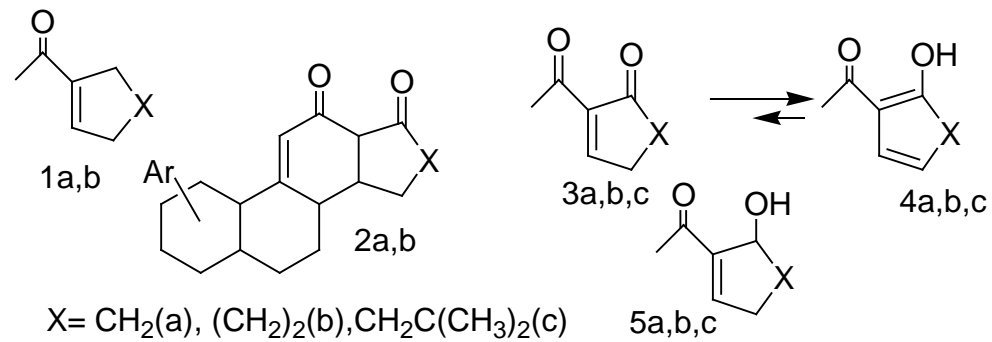<smiles>[R]CC(C1=C(O)CC([R])CC1=O)C1=C(O)CC([R1])([R])CC1=O</smiles>

$6 a, b, c$<smiles>[R]C1CC(=O)C2=C([Y]C(C)=C3C(=O)CC([R])([R])CC32)C1</smiles>

$7 a, b, d, e$<smiles>[R2]C1=C(C)NC(C)=C2C(=O)CC(C)(C)CC12</smiles>

8a,b,c

Figure 1. Acetylcycloalkens and substances obtained from acetylcyclohexadienols. $\mathrm{R}=\mathrm{H}, \mathrm{R}_{1}=\mathrm{CH}_{3}, \mathrm{R}_{2}=\mathrm{CN}, \mathrm{Y}=\mathrm{O}$ (a); $\mathrm{R}=\mathrm{R}_{1}=\mathrm{CH}_{3}, \mathrm{R}_{2}=\mathrm{COCH}_{3}$, $\mathrm{Y}=\mathrm{O}$ (b); $\mathrm{R}=\mathrm{CH}_{3}, \mathrm{R}_{1}=\mathrm{H}, \mathrm{R}_{2}=\mathrm{CO}_{2} \mathrm{CH}_{2} \mathrm{CH}_{3}$ (c); $\mathrm{R}=\mathrm{R}_{1}=\mathrm{H}, \mathrm{Y}=\mathrm{NH}$ (d); $\mathrm{R}=\mathrm{R}_{1}=\mathrm{CH}_{3}, \mathrm{Y}=\mathrm{NH}(\mathrm{e})$. 
hexenones with olefins [20] and enols [21] were studied. This article describes the synthesis of tri-and tetracycliccompounds via reaction of ketodienols $(\mathbf{4 b}, \mathbf{c})$ with 1 , 3-decalindions and 4-hydroxycoumarins. Besides, data on biological testing for some of the resulting coumarine derivatives are also described in the article.

\section{Experimental}

\subsection{General}

The reaction course and purity of the products obtained were monitored by TLC on Silufol 254 using 1:2 etherhexane as the eluent with visualization by UV light or iodine vapor. The melting points were determined on a Boetius block. The IR spectra were taken on a UR-20 spectrometer for KBr pellets. The UV spectra were taken on a Specord M-40 spectrometer for solutions in ethanol. The mass spectra were taken on a Varian MAT-311 mass spectrometer with direct sample inlet. The ionizing voltage was $70 \mathrm{eV}$. The PMR and ${ }^{13} \mathrm{C}$ NMR spectra were taken on a Bruker AC-200 spectrometer at 200 and $50 \mathrm{MHz}$, respectively. The ${ }^{13} \mathrm{C}$ NMR spectra were taken with proton decoupting. The results of elemental analyses were in agreement with those calculated. Decalindions (9a, b) were prepared as it is descried in [22] via the reaction 1-acetylcyclohexen with malonic ester. 4-Hydroxycoumarins (13a, b) were obtained from phenols or resorcinol as it is descried in [23]. Using 2-acetylcy-clohexen-1,3-dions as starting materials acetylcyclohexadienols $(\mathbf{4 b} \mathbf{b}, \mathbf{c})$ were prepared in accordance with our method [12] previously described.

\subsection{General Procedure for Synthesis of Tricycles (10a, b and 14a, b)}

To a solution of $70 \mathrm{mg}$ ( 3.1 mmole) sodium metal in $30 \mathrm{ml}$ ethanol was added, after cooling, 9.23 mmole one of bicycles (9a,b or 13a,b) and, 20 min later, 9.23 mmole ketodienol (4c) and the mixture kept at room temperature. After $24 \mathrm{~h}$ the ethanol was evaporated in vacuum and the residue treated with $5 \% \mathrm{HC}$ (30 ml) and extracted with chloroform and the extract dried over magnesium sulfate. Evaporation of the solvent yielded:

2(2-acetyl-5,5-dimethyl-3-oxocyclohexyl)-cis-1,2,3,4,4a,5,6,7,8,8a-decahydronaphthalen-1,3-dione (10a), yield $=95 \%$; m.p. $152^{\circ} \mathrm{C}-154^{\circ} \mathrm{C}$; IR spectrum, $v, \mathrm{~cm}^{-1}: 1590-1600,1705,3200 ;{ }^{1} \mathrm{H}$ NMR spectrum $\left(\mathrm{CDCl}_{3}, \delta\right.$, ppm, J, Hz): 1.02 (6H, s, $\left.\mathrm{CH}_{3}\right), 1.08$ (6H, s, $\left.\mathrm{CH}_{3}\right), 2.04$ (3H, s, $\left.\mathrm{COCH}_{3}\right), 1.00-2.60$ (18H, m), 15.08 (1H, br s, enol-OH); Mass spectrum: $\mathrm{m} / \mathrm{z} 332[\mathrm{M}]^{+}, 314,289$.

2(2-acetyl-5,5-dimethyl-3-oxocyclohexyl)-4-carboethoxy-cis-1,2,3,4,4a,5,6,7,8,8a-decahydronaphthalen-

1,3-dione (10b), yield $=92 \%$; m.p. $120^{\circ} \mathrm{C}-122^{\circ} \mathrm{C}$; UV spectrum, $\lambda_{\max ,}, \mathrm{nm}(\log \varepsilon): 284(4,28)$; IR spectrum, $v$, $\mathrm{cm}^{-1}$ : 1608, 1632, 1709, 1742,3150, 3300; ${ }^{1} \mathrm{H}$ NMR spectrum $\left(\mathrm{CDCl}_{3}, \delta, \mathrm{ppm}, \mathrm{J}, \mathrm{Hz}\right): 0.98\left(6 \mathrm{H}, \mathrm{s}, \mathrm{CH}_{3}\right), 1.06$ (6H, s, $\left.\mathrm{CH}_{3}\right), 1.26\left(6 \mathrm{H}, \mathrm{t}, \mathrm{J}=7.0 \mathrm{~Hz}, \mathrm{CH}_{3}\right), 2.07\left(3 \mathrm{H}, \mathrm{s}, \mathrm{COCH}_{3}\right), 1.00-2.60(17 \mathrm{H}, \mathrm{m}), 3.45(2 \mathrm{H}, \mathrm{q}, \mathrm{J}=7.0 \mathrm{~Hz}$, $\mathrm{CH}_{2}$ ), 15.20 (1H, br s, enol-OH); Mass spectrum: $\mathrm{m} / \mathrm{z} 404[\mathrm{M}]^{+}, 386,361,238$.

3-(2-Acetyl-5,5-dimethyl-3-oxocyclohexyl)-2H-chromene-4-ol-2-on (14a), yield $=93 \%$; m.p. $181^{\circ} \mathrm{C}$ $183^{\circ} \mathrm{C}$; UV spectrum, $\lambda_{\max ,}, \mathrm{nm}(\log \varepsilon): 206$ (4,44), 215 (4.27), 275 (4.08), 284 (4.13), 308 (4.15), 320 (4.04); IR spectrum, $v, \mathrm{~cm}^{-1}: 1252,1380,1578,1625,1700,1713,2965,3365 ;{ }^{1} \mathrm{H}$ NMR spectrum $\left(\mathrm{CDCl}_{3}, \delta, \mathrm{ppm}, \mathrm{J}, \mathrm{Hz}\right)$ : $1.00\left(3 \mathrm{H}, \mathrm{s}, \mathrm{CH}_{3}\right), 1.10\left(3 \mathrm{H}, \mathrm{s}, \mathrm{CH}_{3}\right), 2.28\left(3 \mathrm{H}, \mathrm{s}, \mathrm{COCH}_{3}\right), 1.20-4.00(4 \mathrm{H}, \mathrm{m}), 7.30-8.10(4 \mathrm{H}, \mathrm{m}), 15.00(1 \mathrm{H}$, br s, enol-OH); Mass spectrum: $m / z 328[\mathrm{M}]^{+}, 310,285$.

3-(2-Acetyl-5,5-dimethyl-3-oxocyclohexyl)-2H-chromene-4,7-diol-2-on (14b), yield = 92\%; m.p. $224^{\circ} \mathrm{C}$ $230^{\circ} \mathrm{C}$ (dec); IR spectrum, $v, \mathrm{~cm}^{-1}: 1245,1401,1568,1620,1662,1722,2965,3250 ;{ }^{1} \mathrm{H}$ NMR spectrum $\left(\mathrm{CDCl}_{3}\right.$, $\delta$, ppm, J, Hz): $1.02\left(6 \mathrm{H}, \mathrm{s}, 2 \mathrm{CH}_{3}\right), 2.02\left(3 \mathrm{H}, \mathrm{s}, \mathrm{COCH}_{3}\right), 0.80$ - $3.50(5 \mathrm{H}, \mathrm{m}), 6.80-6.90(1 \mathrm{H}, \mathrm{m}), 7.90(1 \mathrm{H}, \mathrm{d}$, $\mathrm{J}=8.0 \mathrm{~Hz}) 15.20\left(1 \mathrm{H}\right.$, br s, enol-OH); Mass spectrum: $\mathrm{m} / \mathrm{z} 344[\mathrm{M}]^{+}, 326$.

12-Methyl-6,11-dioxa-9-hydroxy-D-homo-l,3,5(10)-tetraen-7,17a-dione (15). To a solution of $1.62 \mathrm{~g}$ (10 mmole) 4-hydroxycoumarin (13a) in $60 \mathrm{ml}$ chloroform was added $1.38 \mathrm{~g}$ (10 mmole) freshly-prepared [12] acetylcyclohexadienol (4b) in $150 \mathrm{ml}$ ether and the mixture held at $+10^{\circ} \mathrm{C}$ for $24 \mathrm{~h}$. The solvent was evaporated and the residue separated on a chromatograph column (silicagel 100/160 m, $16 \mathrm{~cm}$, ethyl acetate). The yield was $2.4 \mathrm{~g}$ (80\%) hydroxydiketone 15 and $0.12 \mathrm{~g}(9 \%)$ of the dimer [13] of acetylcyclohexadienol. M.p. (15) $178^{\circ} \mathrm{C}-180^{\circ} \mathrm{C}$; IR spectrum, $v, \mathrm{~cm}^{-1}: 1572,1620,1673,1713,3300 ;{ }^{1} \mathrm{H}$ NMR spectrum $\left(\mathrm{CDCl}_{3}, \delta, \mathrm{ppm}, \mathrm{J}, \mathrm{Hz}\right): 1.30$ - $2.30(6 \mathrm{H}$, m, 3 $\left.3 \mathrm{CH}_{2}\right), 2.20\left(3 \mathrm{H}, \mathrm{s}, \mathrm{COCH}_{3}\right), 2.88(1 \mathrm{H}, \mathrm{d}, \mathrm{J}=2.5 \mathrm{~Hz}), 3.85(1 \mathrm{H}, \mathrm{m}), 6.60(1 \mathrm{H}, \mathrm{br} \mathrm{s}, \mathrm{OH})(1 \mathrm{H}, \mathrm{m}), 7.20-8.00$ $(4 \mathrm{H}, \mathrm{m}) ;{ }^{13} \mathrm{C}$ NMR spectrum $\left(\mathrm{CDCl}_{3}, \delta, \mathrm{ppm}\right): 18.61,27.71,29.79,32.70,38.48,53.42,99.44,103.19,114.64$, 116.61, 123.11, 124.06, 132.19, 153.00, 161.91, 162.26, 210.59. Mass spectrum: m/z $300[\mathrm{M}]^{+}, 282,257$. 


\subsection{General Procedure for Synthesis of Tetracycles (11a, b and 16a, b, c)}

To a solution (2 mmole) one of the compounds (14a, b, 15) in $200 \mathrm{ml}$ benzene was added $1.0 \mathrm{~g}_{2} \mathrm{O}_{5}$ and the mixture heated $3 \mathrm{~h}$ at bp and then filtered through a $1 \mathrm{~cm}$ layer of $\mathrm{A}_{2} \mathrm{O}_{3}$. The solvent was evaporated and the residue recrystallized from a mixture of chloroform, ether and hexane. Yield:

2,2,5-trimethyl-1,2,3,4,7,7a,8,9,10,11,11a,12-dodecahydro-12bH-benzo[d]naphtho[b]pyran-4,12-dion (11a), yield $=89 \%$; m.p. $175^{\circ} \mathrm{C}-177^{\circ} \mathrm{C}$; IR spectrum, $v, \mathrm{~cm}^{-1}: 1610,1665,1710 ;{ }^{1} \mathrm{H}$ NMR spectrum $\left(\mathrm{CDCl}_{3}, \delta\right.$, ppm, J, Hz): 1.00 (3H, s, $\left.\mathrm{CH}_{3}\right), 1.10\left(3 \mathrm{H}, \mathrm{s}, \mathrm{CH}_{3}\right), 2.05\left(3 \mathrm{H}, \mathrm{s}, \mathrm{CH}_{3}\right), 1.00-4.00(17 \mathrm{H}, \mathrm{m}) ;$ Mass spectrum: $\mathrm{m} / \mathrm{z}$ $358[\mathrm{M}]^{+}, 343$.

7-carboethoxy-2,2,5-trimethyl-1,2,3,4,7,7a,8,9,10,11,11a,12-dodecahydro-12bH-benzo[d]naphtho[b]pyr an-4,12-dion (11b), yield $=89 \%$; m.p. $186^{\circ} \mathrm{C}-188^{\circ} \mathrm{C}$; IR spectrum, $v, \mathrm{~cm}^{-1}: 1612,1662,1705,1740 ;{ }^{1} \mathrm{H}$ NMR spectrum $\left(\mathrm{CDCl}_{3}, \delta, \mathrm{ppm}, \mathrm{J}, \mathrm{Hz}\right): 0.98\left(3 \mathrm{H}, \mathrm{s}, \mathrm{CH}_{3}\right), 1.08\left(3 \mathrm{H}, \mathrm{s}, \mathrm{CH}_{3}\right), 1.30\left(3 \mathrm{H}, \mathrm{t}, \mathrm{J}=7.5 \mathrm{~Hz}, \mathrm{CH}_{3}\right), 2.05(3 \mathrm{H}, \mathrm{s}$, $\left.\mathrm{CH}_{3}\right), 4.20\left(2 \mathrm{H}, \mathrm{q}, \mathrm{J}=7.5 \mathrm{~Hz}, \mathrm{CH}_{2}\right), 1.00-4.00(13 \mathrm{H}, \mathrm{m})$; Mass spectrum: $\mathrm{m} / \mathrm{z} 386[\mathrm{M}]^{+}, 371$.

12-methyl-6,11-dioxa-D-homo-1,3,5(10),8,12-pentaen-7,17a-dione (16a), yield = 95\%; m.p. $146^{\circ} \mathrm{C}-148^{\circ} \mathrm{C}$; UV spectrum, $\lambda_{\max }, \mathrm{nm}(\log \varepsilon): 210$ (4.41), 260 (4.30), 302 (3.95); IR spectrum, $v, \mathrm{~cm}^{-1}: 1380,1392,1610,1665$, $1715 ;{ }^{13} \mathrm{C}$ NMR spectrum $\left(\mathrm{CDCl}_{3}, \delta\right.$, ppm): 17.25, 21.60, 29.89, 32.08, 41.05, 104.00, 113.57, 114.45, 116.67, 122.57, 124.25, 132.30, 151.45, 152.70, 154.82, 161.32, 201.29; Mass spectrum: $\mathrm{m} / \mathrm{z} 282$ [M] ${ }^{+}, 254$.

12,16,16-trimethyl-6,11-dioxa-3-hydroxy-D-homo-1,3,5(10),8,12-pentaen-7,17a-dione (16b), yield = 91\%; m.p. $256^{\circ} \mathrm{C}-268^{\circ} \mathrm{C}$ (dec.); IR spectrum, $v, \mathrm{~cm}^{-1}: 1585,1613,1655,1695,1715,3340 ;{ }^{1} \mathrm{H}$ NMR spectrum $\left(\mathrm{CDCl}_{3}, \delta, \mathrm{ppm}, \mathrm{J}, \mathrm{Hz}\right): 1.00\left(3 \mathrm{H}, \mathrm{s}, \mathrm{CH}_{3}\right), 1.08\left(3 \mathrm{H}, \mathrm{s}, \mathrm{CH}_{3}\right), 2.24\left(3 \mathrm{H}, \mathrm{s}, \mathrm{CH}_{3}\right), 1.10-2.40(4 \mathrm{H}, \mathrm{m}), 3.70(1 \mathrm{H}, \mathrm{d}$, $\mathrm{J}=10.0 \mathrm{~Hz}, \mathrm{CH}), 6.86-6.96(2 \mathrm{H}, \mathrm{m}), 7.64(1 \mathrm{H}, \mathrm{d}, \mathrm{J}=8.0 \mathrm{~Hz}, \mathrm{CH})$; Mass spectrum: $\mathrm{m} / \mathrm{z} 326[\mathrm{M}]^{+}, 298$.

12,16,16-Trimethyl-6,11-dioxa-D-homo-l,3,5(10),8,12-pentaen-7,17-dione (16c), yield $=97 \%$; m.p. $197^{\circ} \mathrm{C}$ - $199^{\circ} \mathrm{C}$; UV spectrum, $\lambda_{\max }$, $\mathrm{nm}(\log \varepsilon)$ : 208 (4.51), 249 (4.23), 260 (4.36), 302 (3.90); IR spectrum, $v, \mathrm{~cm}^{-1}$ : 1360, 1500, 1585, 1615, 1650, 1715; ${ }^{1} \mathrm{H}$ NMR spectrum $\left(\mathrm{CDCl}_{3}, \delta, \mathrm{ppm}, \mathrm{J}, \mathrm{Hz}\right): 1.02\left(3 \mathrm{H}, \mathrm{s}, \mathrm{CH}_{3}\right), 1.10(3 \mathrm{H}, \mathrm{s}$, $\left.\mathrm{CH}_{3}\right), 2.26$ (3H, s, $\left.\mathrm{CH}_{3}\right), 1.40-2.90(4 \mathrm{H}, \mathrm{m}), 3.65(1 \mathrm{H}, \mathrm{d}, \mathrm{J}=12.0 \mathrm{~Hz}, \mathrm{CH}), 7.20-7.90(4 \mathrm{H}, \mathrm{m}) ;{ }^{13} \mathrm{C}$ NMR spectrum $\left(\mathrm{CDCl}_{3}, \delta, \mathrm{ppm}\right): 16.92,28.08,29.27,32.11,32.20,43.27,55.19,104.23,113.65,114.53,116.73,122.50$, 124.23, 132.11, 151.16, 152.70, 155.02, 161.02, 201.16. Mass spectrum: m/z $310[\mathrm{M}]^{+}, 282$.

\subsection{Testing the Toxicity and Anticoagulative Effects}

Acute toxicity of the intraperitoneally-injected compounds was studied in non-inbred male mice, with the signs of total toxic effect as well as alterations in the animal appearance and behavior being taken into account.

Haemocoagulation-related effects of the compounds administered perorally at doses of 5 and 10 per cent of LD-50 24 hours before data registration, were studied in male rats in terms of haemocoagulogram parameters.

\section{Results and Discussion}

\subsection{Synthesis}

In order to access to the tetracyclic analogues of compounds (7a, b) the interaction endion (4c) with bicyclic $\beta$-diketones (9a, b) was studied. As with 1,3-cyclohexanedione 1,3-decalindions (9a, b) in the presence of sodium methylate easily react with ketodienol (4c), giving tricyclic tetraketons $(\mathbf{1 0 a}, \mathbf{b})$ (Scheme 1 ). The structure of the compounds corresponds to the spectral data and elemental analyses.

Heating of any tricycle (10a, b) in benzene in the presence of $\mathrm{P}_{2} \mathrm{O}_{5}$ in both cases gave a single compound, which is attributed to the structures (11a, b), rather than their isomers (12a, b), because the authors of articles [24] [25] showed that the formation of $\Delta^{2}$-enol derivatives 1,3-decalindions is observed much more likely than their $\Delta^{1}$-analogues. Attempts to carry out intramolecular aldol condensation by heating the compounds (10a, b) in the medium $\mathrm{MeONa} / \mathrm{MeOH}$ led to retro-Michael decomposition. It should be noted that the tetracyclic skeleton of the type (11a, $\mathbf{b})$ is the base of some natural antibiotics [26].

It is known that coumarines with 3:4-fused ring systems are of great interest to medical chemists due to the broad spectrum of physiological activity [27] [28]. That is why we studied the reaction of ketodienols (4b, c) with 4-hydroxycoumarins (13a, b) (Scheme 2).

Substituted ketodienol (4c) reacted with 4-hydroxycoumarins (13a, b) to give good yilds of tricyclic products (14a, b), whereas unsubstituted one (4b) reacted with 4-hydroxycoumarins (13a) to form tetracyclic compound (15). It is evident that in the second case [2+4]-cycloaddition reaction was observed whereas in the first case 


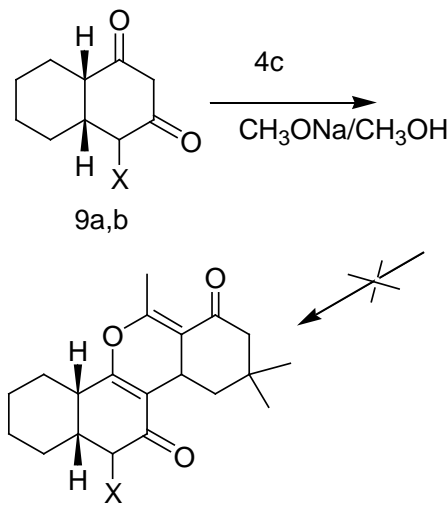

$12 a, b$

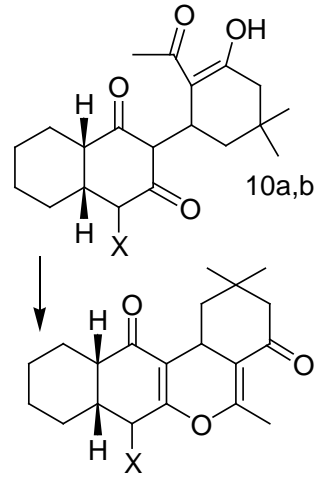

11a,b

Scheme 1. Synthesis of the tetracycles $(11 \mathrm{a}, \mathrm{b}) . \mathrm{X}=\mathrm{H}$ (a), $\mathrm{CO}_{2} \mathrm{CH}_{2} \mathrm{CH}_{3}$ (b).

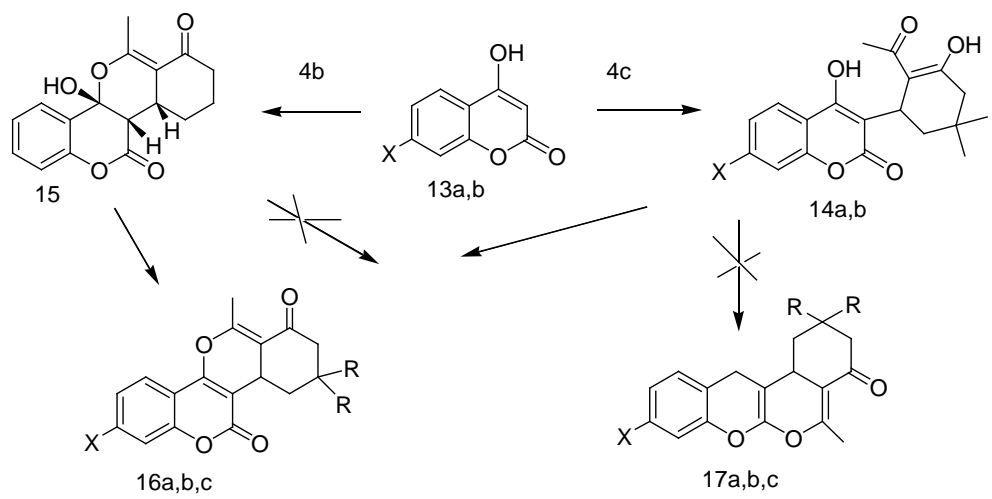

Scheme 2. Synthesis coumarine derivatives. $\mathrm{X}=\mathrm{R}=\mathrm{H}$ (a); $\mathrm{X}=\mathrm{OH}, \mathrm{R}=\mathrm{CH}_{3}$ (b); $\mathrm{X}=\mathrm{H}, \mathrm{R}=\mathrm{CH}_{3}$ (c).

only Michael addition took place.

It is known [21] that 2-Acetyl-2-cyclohexenone (3b) undergoes Diels-Alder reactions with enol ethers.

The structure of the obtained compounds completely agrees with the results of elemental analyses and spectral data. Thus, ${ }^{1} \mathrm{H}-\mathrm{NMR}$ spectra of compounds (14a, b) showed proton signals of cis-ketoenol form ( 15.2 ppm) acetylcyclohexanone moiety. The ${ }^{13} \mathrm{C}-\mathrm{NMR}$ spectrum of (15) exhibited carbon signals of ketone (210.59 ppm) and lactone (161.91 ppm) carbonyl, hemiketal (99.44 ppm) functions.

Dehydration of compounds $(\mathbf{1 4 a}, \mathbf{b})$ and (15), gave 6,11-dioxa-analogs of the steroids. In the ${ }^{13} \mathrm{C}$ NMR spectra of compounds 16a and 16c all the signals could be unequivocally assigned, including lactones (161.02 and $161.32 \mathrm{ppm}$ ) and 17a-ketones (201.16 and $201.29 \mathrm{ppm})$ respectively. The formation of compounds (15, 16b, c) rather than an alternative structure of the type of $(\mathbf{1 7 a}, \mathbf{b}, \mathbf{c})$ is in accordance with the greater activity of the ketone compared with the lactone carbonyl: in the majority of cases the reaction of 4-hydroxycoumarin and its azaand thiaanalogs takes place with participation of the ketone function [29] [30].

\subsection{Biological Testing}

According to our data, poisoning effects of the toxic doses of the compounds in the mice became obvious within a few hours after the injections. The animals could hardly move and rejected their food. There were numerous skin and internal bleedings. The toxic doses of compounds (14b) and (15) resulted in the death of the mice within the first day after the injections, whereas the compound (14a)—injected animals lived as long as 5 to 6 days. Compound (16c) turned out to be low toxic, with no poisoning effects being registered even in case of its injection at a dose of $3000 \mathrm{mg} / \mathrm{kg}$. The acute toxicity data are shown in Table 1.

Compounds (14a, b) and (15) were tested for anticoagulant activity 24 hours after their peroral administration 
Table 1. Parameters of the acute toxicity of intraperitoneally-injected 4-oxycoumarine derivatives registered in non-inbred mice.

\begin{tabular}{ccc}
\hline Compound & LD-50 & Reliability intervals \\
\hline $14 \mathrm{a}$ & 708 & $500-1008$ \\
$14 \mathrm{~b}$ & 708 & $500-1008$ \\
15 & 1030 & $676-1384$ \\
$16 \mathrm{c}$ & $>3000$ & - \\
\hline
\end{tabular}

Table 2. Effects of 4-oxycoumarine derivative 14a administered perorally 24 hours before the data registration on haemocoagulogram parameters in control $\{C\}$ and test $\{\mathrm{T}\}$ rats.

\begin{tabular}{|c|c|c|c|c|c|c|c|c|c|}
\hline Rats & $\begin{array}{l}\text { LD-50, } \\
\text { percentage }\end{array}$ & $\begin{array}{l}\text { Reaction } \\
\text { time r, } \\
\text { min. }\end{array}$ & $\begin{array}{c}\text { Thrombin } \\
\text { constant K, } \\
\text { min. }\end{array}$ & $\begin{array}{l}\text { Coagulation } \\
\text { constant t min. }\end{array}$ & $\begin{array}{c}\text { Syneresis } \\
\text { constant S }\end{array}$ & $\begin{array}{c}\text { Total } \\
\text { coagulation } \\
\text { index T min. }\end{array}$ & $\begin{array}{l}\text { Maximum } \\
\text { amplitude } \\
\text { Am, mm. }\end{array}$ & $\begin{array}{l}\text { Elasticity } \\
\text { of clot E }\end{array}$ & $\begin{array}{c}\text { Hyper } \\
\text { coagulation } \\
\text { index ci }\end{array}$ \\
\hline $\mathrm{C}$ & & $12.0 \pm 0.6$ & $11.6 \pm 1.6$ & $45.0 \pm 6.4$ & $56.6 \pm 7.6$ & $68.6 \pm 8.0$ & $42.0 \pm 1.9$ & $73.2 \pm 5.7$ & $1.8 \pm 0.1$ \\
\hline $\mathrm{T}$ & 5 & $20.2 \pm 1.0^{*}$ & $16.8 \pm 1.7$ & $52.0 \pm 5.9$ & $68.8 \pm 7.0$ & $89.0 \pm 6.7$ & $43.4 \pm 2.9$ & $78.9 \pm 10.9$ & $1.2 \pm 0.1$ \\
\hline \multicolumn{2}{|c|}{ Effect percentage } & 68.3 & & & & & & & 33.4 \\
\hline $\mathrm{C}$ & & $16.0 \pm 1.2$ & $14.6 \pm 1.5$ & $38.0 \pm 6.4$ & $52.6 \pm 6.5$ & $68.6 \pm 5.5$ & $40.4 \pm 3.3$ & $70.0 \pm 10.4$ & $1.4 \pm 0.1$ \\
\hline $\mathrm{T}$ & 10 & $23.2 \pm 2.4^{*}$ & $42.6 \pm 11.9^{*}$ & $48.0 \pm 6.0$ & $90.6 \pm 8.9^{*}$ & $113.8 \pm 10.6^{*}$ & $31.4 \pm 2.7$ & $47.9 \pm 5.2$ & $0.6 \pm 0.1^{*}$ \\
\hline \multicolumn{2}{|c|}{ Effect percentage } & 45.0 & 191.8 & & 72.2 & 65.9 & & & 57.1 \\
\hline
\end{tabular}

at doses of 0.05 and $0.1 \mathrm{DL}_{50}$. Of the studied compounds, only compound (14a) turned out to show anticoagulant effect.

Compound (14a) administered perorally at a dose of 5 per cent of LD-50 24 hours before the data registration, was found out to result in blood coagulation decrease evidenced, as is shown in Table 2, by enhancing the reaction time $r$ as well as lowering the hypercoagulation index ci in the rats. The dosage growth up to 10 per cent of LD-50 increased to some extent the anticoagulative effects of the compound, which could be seen by the corresponding alterations in the reaction time, thrombin constant, syneresis constant, total coagulation time, hypercoagulation index. These alterations of haemocoagulogram parameters may evidence distortions of blood coagulation phases 1 and 2. The studied compound displayed anticoagulative activity which, however, was sufficiently less than that of coumarine series anticoagulants characterized by indirect effects.

\section{Conclusion}

In conclusion it is necessary to note that heterocycles (11a, b) are of interest as a starting material for further research on the synthesis of carbocyclic steroids. Compounds $(15,16 \mathrm{a}, \mathrm{b}, \mathrm{c})$ are of interest in terms of biological testing for oestrogenic activity because coumarine analogs of steroids are known to show this activity and keep it for much longer period than natural compounds [31].

\section{References}

[1] Rapson, W.S. and Robinson, R. (1935) 307. Experiments on the Synthesis of Substances Related to the Sterols. Part II. A New General Method for the Synthesis of Substituted Cyclohexenones. Journal of the Chemical Society, 1935, 1285-1288. http://dx.doi.org/10.1039/jr9350001285

[2] Hawthorne, J.R. and Robinson, R. (1936) 175. Experiments on Synthesis of Substances Related to Sterols. Part XIII. Hydrocyclopentanophenanthrene Derivatives. Journal of the Chemical Society, 1936, 763-765. http://dx.doi.org/10.1039/jr9360000763

[3] Cagniant (1963) Contribution a L'etude de la Reaction de Condention des Alkanoyl-1-cyclohexene-1 Avec les $\alpha$-Tetralones. Comptes Rendus Hebdomadaires des Seances de l Academie des Sciences, 256, 4674-4676.

[4] Schaefer, M., Weber, J. and Faller, P. (1979) Stereospecific Robinson-Stork Annelation of Heteroaromatic C-dialkylamino Compounds. Synthesis, No. 2, 122-133. http://dx.doi.org/10.1055/s-1979-28583

[5] Jacob, G. and Cagniant, D. (1977) Synthesis of Sulfur or Oxygen Analogs of 6,7,8,12,13,14,16,17-Octahydro-12-oxo15H-cyclopenta[a]phenanthrene and Some Their Methylated Derivatives. Comptes Rendus Hebdomadaires des Seances de l Academie des Sciences, 284, 373-375. 
[6] Robinson, R. and Slater, S.N. (1941) 72. Experiments on Synthesis of Substances Related to Sterols. Journal of the Chemical Society, No. 7, 376-385. http://dx.doi.org/10.1039/jr9410000376

[7] Ashton, M.J., Bailey, A.S. and Jones, E.R.H. (1974) Microbiological Hydroxylation. Part XII. Comparative Behavior of D-Homogonane Ketones and Steroids. Journal of the Chemical Society Perkin I, No. 14, 1658-1665. http://dx.doi.org/10.1039/p19740001658

[8] Akhrem, A.A., Moiseenkov, A.M. and Lakhvich, F.A. (1972) Use of Some 2-Acetyl-2-cyclohexen-1-one Derivatives in the Total Synthesis of Steroids. Russian Chemical Bulletin, 21, 866-868. http://dx.doi.org/10.1007/BF00854489

[9] Lakhvich, F.A., Khripach, V.A., Pyrko, A.N., Antonevich, I.P., Yankova, T.V., Koroleva, E.V. and Akhrem, A.A. (1988) Reductive Cleavage of 4,5-Cycloalkanoisoxazolines. Chemistry of Heterocyclic Compounds, 24, 800-804. http://dx.doi.org/10.1007/BF00633180

[10] Akhrem, A.A., Lakhvich, F.A. and Pyrko, A.N. (1977) Synthesis of 2-Acetyl-5,5-dimethyl-2-cyclohexen-1-ol and 5,5dimethyl-2-( $\alpha$-hydroxyethyl)-2-cyclohexen-1-on. Journal of Organic Chemistry (Russian), 13, 2074-2078.

[11] Akhrem, A.A., Lakhvich, F.A., Khripach, V.A. and Pyrko, A.N. (1990) 2-Acetyl-2-cycloalken-1-ols in MichaelRobinson Annelation Reactions. Journal of Organic Chemistry (Russian), 26, 1932-1938. http://dx.doi.org/10.1002/chin.199109084

[12] Akhrem, A.A., Lakhvich, F.A. and Pyrko, A.N. (1983) Reaction of 2-acetyl-2-cycloalken-1-ones with Cyclic $\beta$-Diketones. Journal of Organic Chemistry (Russian), 19, 2322-2328.

[13] Ozols, Ya.Ya., Pyrko, A.N., Lakhvich, F.A., Vigante, B.A., Dubure, R.R., Dubur, G.Ya. and Akhrem, A.A. (1990) Synthesis of Decahydrophenanthridine-1,7-dione and Hexahydroisoquinol-8-one Derivatives in the Deaction of 2-acetyl-2-cyclohexene-1-ones with Conjugated Enaminocarbonyl Compounds. Chemistry of Heterocyclic Compounds, 26, 58-62.

[14] Ozols, Ya.Ya., Pyrko, A.N., Vigante, B.A., Dubure, R.R. and Dubur, G.Ya. (1992) Synthesis of Phenyl-Substituted Derivatives of Decahydro-1,7-phenanthridinedione and Hexahydro-8-isoquinolone. Chemistry of Heterocyclic Compounds, 28, 530-534. http://dx.doi.org/10.1007/BF00475250

[15] Reich, H.J., Renga, J.M. and Reich, I.L. (1975) Organoselenium Chemistry. Conversion of Ketones to Enones by Selenoxide Syn Elimination. Journal of the American Chemical Society, 97, 5434-5447. http://dx.doi.org/10.1021/ja00852a019

[16] Liotta, D., Saindane, M., Barnum, C., Ensley, H. and Balakrishnan, P. (1981) Reactions Involving Selenium Metal as an Electrophile. 2. A General Pprocedure for the Preparation of Uunsaturated $\beta$-Dicarbonyl Compounds. Tetrahedron Letters, 22, 3043-3046. http://dx.doi.org/10.1016/S0040-4039(01)81822-0

[17] Oliveira-Ferrer, L., Schmidt, K. and Margaretha, P. (2001) Synthesis of Nonenolizing 2-Acylcyclohex-2-enones. Helvetica Chimica Acta, 84, 3818-3821. http://dx.doi.org/10.1002/1522-2675(20011219)84:12<3818::AID-HLCA3818>3.0.CO;2-R

[18] Sheng, Sh.R., Liu, X.L. and Wang, X.C. (2003) Synthesis of $\alpha, \beta$-Unsaturated Ketones and Esters Using PolymerSupported Selenium Bromide. Journal of the Chinese Chemical Society, 50, 279-281.

[19] Renga, J.M. and Reich, H.J. (1988) $\alpha, \beta$-Dehydrogenationof $\beta$-Dicarbonyl Compounds by Selenoxide Elimination: 2Acetyl-2-cyclohexen-1-one. Organic Syntheses, 6, 23-24.

[20] Oliveira-Ferrer, L. and Margaretha, P. (1999) Synthesis and Photoreactivity of a 2-Pivaloylcyclohex-2-enone. Journal of Chemical Research, Synopses, No. 3, 204-205. http://dx.doi.org/10.1039/a808422j

[21] Snider, B.B. (1980) Diels-Alder Reactions of 2-acetyl-2-cyclohexenone with Enol Ethers and Emamines. Tetrahedron Letters, 21, 1133-1136. http://dx.doi.org/10.1016/S0040-4039(01)83932-0

[22] Kon, G.A.R. and Qudrat-i-Khuda, M. (1926) CCCCX.-Preparation of Cis-o-carboxycyclohexaneacetic Acid. Journal of the Chemical Society, 1926, 3071-3073. http://dx.doi.org/10.1039/jr9262903071

[23] Shah, V., Bose, J. and Shah, R. (1960) New Synthesis of 4-Hydroxycoumarins. Journal of Organic Chemistry, 25, 677-678. http://dx.doi.org/10.1021/jo01074a630

[24] Tamm, Ch. and Albrecht, R. (1960) Die Enolisation von Cholestandion-(1,3) und Verwandten Cyclischen $\beta$-Dicarbonylverbindungen. Helvetica Chimica Acta, 43, 768-782. http://dx.doi.org/10.1002/hlca.19600430320

[25] Muhle, H. and Tamm, Ch. (1962) Über cyclische $\beta$-Diketone. 3. Mitteilung. Die Methylierung von ( \pm )-cis- und ( \pm )-trans-Decalindion-(1,3), sowie von ( \pm )-2-Methyl-trans-decalindion-(1,3) mit Diazomethan. Helvetica Chimica Acta, 45, 1475-1485. http://dx.doi.org/10.1002/hlca.19620450513

[26] Tanaka, H., Iton, J., Ikushima, H., Okamoto, M., Kawai, J. and Imanaka, H. (1980) Structure Elucidation and Synthesis of a New Anticoccidial Substance Isolated from Streptomycesauranticolor. Tetrahedron Letters, 21, 4359-4360. http://dx.doi.org/10.1016/S0040-4039(00)77857-9 
[27] Darbarwar, M. and Sundaramurthy, V. (1982) Synthesis of Coumarins with 3:4-Fused Ring Systems and Their Physiological Activity. Synthesis, No. 5, 337-388. http://dx.doi.org/10.1055/s-1982-29806

[28] Sosnovskikha, V.Ya., Moshkina, V.S. and Kodessb, M.I. (2008) A Reinvestigation of the Reactions of 3-Substituted Chromones with Hydroxylamine. Unexpected Synthesis of 3-Amino-4H-chromeno[3,4-d]isoxazol-4-one and 3-(Diaminomethylene)chroman-2,4-dione. Tetrahedron Letters, 49, 6856-6859. http://dx.doi.org/10.1016/j.tetlet.2008.09.091

[29] Wolfbeis, O.S. (1982) Darstellung Pyronokondensierter 2-Pyridone, Cumarine und 2-Chinolone mit Hilfe derKappeMayer-Variante dervon Pechmann-Reaktion. Monatshefte fiir Chemie/Chemical Monthly, 113, 365-370. http://dx.doi.org/10.1007/BF00799563

[30] Sharanin, Yu.A., Goncharenko, M.P. and Litvinov, V.P. (1998) Reactions of Carbonyl Compounds with $\alpha, \beta$-Unsaturated Nitriles as a Convenient Pathway to Carbo- and Heterocycles. Russian Chemical Review, 67, 393-422. http://dx.doi.org/10.1070/RC1998v067n05ABEH000371

[31] Caselli, A.S., Collins, D.J. and Stone, G.M. (1982) The Structure and Function of Oestrogens. III. 3,17ß-Dihydroxy6-oxaoestra-1,3,5(10),8(9)-tetraen-7-one and Related Steroidal Coumarins. Australian Journal of Chemistry, 35, 799808. http://dx.doi.org/10.1071/CH9820799 